DOI: https://doi.org/10.46630/phm.12.2020.30

Сара Н. Немат ${ }^{1}$

Оригинални научни рад

Универзитет у Нишу

УДК 821.163.41.01

Филозофски факултет

821.163.41.09 Доментијан

Департман за србистику

Примљен: 17. 10. 2020.

\title{
ИНТЕРТЕКСТУАЛНЕ ВЕЗЕ У ПОДЖАНРОВИМА ДОМЕНТИЈАНОВОГ ЖИТИЈА СВЕТОГА САВЕ
}

\begin{abstract}
У раду се дефинишу (под)жанровске одлике Доментијановог Житија Светога Саве и утврђују се интертекстуалне везе у њима. Уочено је да се сваки поджанр позива на ауторитативне (византијске) жанрове и да је конституисан по узору на њих. Притом, жанрови у старој српској књижевности не постоје изоловано, већ су у односу међусобног прожимања. Циљ овог рада јесте утврђивање извора цитатности у поджанровима, као и указивање на степен присуства интертекстуалности у Доментијановом Житију Светога Саве.
\end{abstract}

Кључне речи: житије, (под)жанр, молитва, похвала, плач, посланица, беседа, интертекстуалност, интертекстуалне везе, Доментијан

\section{1. Увод}

За српску средњовековну књижевност значајно је начело жанра, док је ауторско начело својствено савременој књижевности. Књижевни жанрови који се јављају у српској средњовековној књижевности преузети су из византијске књижевности. Притом, ти жанрови нису изоловани једни од других, већ чине одређени систем који се кроз историју мењао. Они стоје у односу узајамног прожимања, јер један жанр или више жанрова улази у састав другог. У старој српској књижевности, жанрови су, поред књижевних, имали и ванкњижевне функције, при чему се мисли на њихове богослужбене, правне и дипломатске функције (KOSTIĆ TMUŠIĆ 2017: 45). Најважнији принцип у средњовековној књижевности јесте хијерархијска потчињеност једних текстова другима у зависности од првобитне светости и актуелне функције датог текста (NAUMOV 2009: 9). Житије је примарни прозни жанр, обимнија књижевна целина која у своју структуру може примити и друге жанрове. Интерполирани

\footnotetext{
${ }^{1}$ saranemat3@gmail.com
} 
у житије, они од жанрова постају поджанрови. У житију се у функцији поджанрова могу наћи прозни, поетски и прелазни књижевни жанрови. Прозни жанрови који се најчешће интерполирају у житија јесу посланица и слово (беседа). Када је реч о поетским поджанровима, највише се уноси служба, а у оквиру ње могу се јавити: тропар, стихира, кондак, канон и акатист. У структури житија чести су и прелазни жанрови од којих су најфреквентнији: похвала, молитва и плач. У српској средњовековној књижевности има и мешања жанрова, па тако настају „похвално слово“ или „плачевна посланица““ (BOJOVIĆ 2011: 24).

Српски средњовековни (под)жанрови формално су конституисани по угледу на византијске жанрове, а садржински по угледу на ауторитативне текстове. ${ }^{2}$ Присуство Светог писма, Свете Литургије и Светих Отаца у средњовековном делу одраз је „,тројне литерарне светости“ (BOJOVIĆ 2009a: 39), односно интертекстуалности. По дефиницији Ане Бужињске, „интертекстуалност је концепција према којој сваки књижевни текст апсорбује у себе раније текстове, тако да представља мрежу различитих позајмица које су се у њему наслагале“ (BUŽINJSKA, MARKOVSKI 2009: 363), што се јасно уочава у српским средњовековним књижевним текстовима. Говорећи о присуству интертекстуалности у Житију Светога Cuмeона Светога Саве, Маја Анђелковић закључује да:

„највећи део корпуса средњовековне књижевности чине дела која се директно или индиректно везују за потребе цркве, литургијски живот, канонске и световне правне прописе. Као таква, она се нужно позивају на већ добро познате текстове, доказујући њиховим постојањем сопствену недељивост од хришћанске традиције, стварајући библијску аргументацију реченог, истичући истинитост сопствених речи у којима обитава света Реч. Интертекстуалност је, дакле, поетичка одлика средњовековне књижевности (2019: 329).

\section{2. Молитва}

Када је реч о конституисању српског средњовековног житија, молитва је један од најзначајнијих књижевних жанрова са изразито поетским елементима. У црквеној књижевности, молитва се јавља као самосталан жанр, али када је у саставу обимније књижевне целине, односно житија, она има функцију поджанра. Због својих особина, молитва се сврстава у прелазне жанрове старе српске књижевности. Ђорђе Трифуновић у Азбучнику српских средњовековних књижевних појмова молитве дели на унутрашње (када се врше мислима) и спољашње (када се гласно

${ }^{2}$ Ауторитативни текстови подразумевају библијске, светоотачке и литургијске текстове. 
изражавају појединим речима). Поред тога, оне се деле и на молитве хвале и слављења, молитве благодарности и молитве мољења. Сматра се да је врхунац вере у молитвама хвале, љубави у молитвама благодарности и наде у молитвама мољења (1990: 159).

О значају и снази молитве говори се и у Светом писму. У Јеванђељу по Луки, имајући у виду важност молитвеног обраћања Богу, Христови ученици ишту од свога учитеља да их научи молити се хришћанском молитвом речима: „Господе, научи нас молити се“ (LK. 11, 1), а Христос им „каза пак и причу како треба свагда да се моле и да не клону“ (LK. $18,1)$, јер се молитва може казивати на сваком месту и у свако време, макар и мисаоним устима. Молитва је, дакле, аманет који Христос оставља својим ученицима и следбеницима, а његове речи: „Све што иштете у својој молитви, вјерујте да ћете примити и биће вам“ (МK. 11, 24) представљају суштину молитвеног значаја.

Молитва је потврда богоугодног и подвижничког живота личности која се у житију глорификује. Кроз призму молитве преламају се зраци свести глорификованог јунака и она представља најбољу рефлексију његовог унутрашњег бића. Свети Сава је аутор првих српских молитава и тек са Светим Савом молитвени живот у Срба доживљава своју пуноћу. У Доментијановом Житију Светога Саве, Савин живот омеђен је и прожет молитвом. Најбоље је то описано речима: „Све што се у том животу догодило стало је између две молитве“ (BOJOVIĆ 2002: 5), и у њима је садржана суштина Савиног живота.

Виђен Доментијановим очима, Савин живот почиње молитвом „богочастиве“ (1988: 55) Ане и „самодржавног господина“ (1988: 55) Стефана да им Господ подари чедо које ће посветити Богу и научити богоугодном животу. На овај начин имплицитно се прави паралела са Cmapuм заветом, односно са Саром и Аврамом, Рахиљом и Јаковом, Манојем и његовом женом, али и са Новим заветом, односно са Захаријом и Јелисаветом, да споменемо само неке библијске личности које су у позним годинама добиле Богом дарована им чеда.

Друга молитва која је важна за Савин живот јесте његова молитва за исход душе. Она представља најзначајнију молитву у структури Житија Светога Саве. Дакле, Сава је пре свога доласка на овај свет измољен молитвом, али и пред крај овоземаљског живота он се молитвено обраћа Богу са вером да ће се настанити у вечном животу. Сваки стих ове молитве представља навод из Давидовог Псалтира, а она сама представља мрежу интертекстуалних веза са Псалмима Давидовим:

„Повиках у печали мојој ка Господу Богу мојем (PS. 119, 1), Господе услушај молитву моју, и вапај мој нека дође ка теби; Не одврати лица твога од мене; у који дан будем тужио, приклони ка мени ухо твоје, И 
брзо ме услишај; јер ишчезоше дани моји као дим, и кости моје сметоше се веома (PS. 101, 1-5). И малакса у мени дух мој, и срце моје смете се у мени. И остави ме сила моја (PS. 142, 4). И подигох ка теби руке моје, и душа моја као безводна земља жели твога помиловања (PS. 38, 11), и брзо ме услишај, Господе, сконча дух мој, и не одврати лица твога од мене (PS. 142, 6-7). И избави ме од непријатеља мојих, Господе; Ка теби прибегох, и дух твој добри водиће ме на земљу праву; Ради твога имена, Господе, оживећеш ме по правди твојој; И изведи из печали душу моју, и милошћу твојом истреби непријатеље моје, и погуби све који досађују души мојој, јер сам ја слуга твој (PS. 142, 9-12). Услишај ме правдом твојом и не уђи у суд са слугом твојим јер се пред тобом неће оправдати ниједан живи (PS. 142, 1-2). И изведи из тамнице душу моју, да се исповеда имену твоме (PS. 141, 7)“ (DOMENTIJAN 1988: 222). ${ }^{3}$

Ова молитва израз је Доментијанове велике богословске учености, јер само боговидни ум може створити овакав мозаик најразличитијих стихова Псалама Давидових.

Између ове две стале су све друге молитве које представљају одраз Савиног подвижничког и молитвеног живота. То су: молитве Богородици, молитве Богу, светогорске молитве, ватопедске молитве, молитве благодарности и молитве у разним другим потребама. Њих Драгиша Бојовић издваја у Молитвама Светога Саве 4 и на тај начин саставља својеврсну антологију молитава из Доментијановог и Теодосијевог дела.

Прва молитва изговорена на Светој Гори којом се Сава обраћа Богу из захвалности што је примљен на Свету Гору Атонску је молитва мољења Господу да управи стопе његове на прави пут и дела добра: „Господе, управи ме на пут твоје милости“ (PS. 85, 11). Сава се обраћа Богу као своме покровитељу: „из утробе матере моје ти си покровитељ мој“ (DOMENTIJAN 1988: 59), што је директна алузија на прву молитву у овоме житију, а то је молитва Ане и Немање да им Бог подари чедо, али истовремено и парафраза 70. Псалма: „Тебе се држим од рођења, од утробе матере моје Ти си бранич мој“ (PS. 70, 6).

Сава се често молио са рукама подигнутим ка небу, „што представља телесни и визуелни одраз тежње човекове душе ка Богу“ (BOJOVIĆ 2002: 16). А чему би другом тежио он, „богоизабрана зрака“ (DOMENTIJAN 1988: 94) светлости Христове? Сава подиже своје руке ка Господу на-

\footnotetext{
${ }^{3}$ Слична овој молитви је молитва за исход душе коју изговара Свети Симеон у Савином Житију Светог Симеона уочи свога упокојења, што је сведочанство о томе да је Доментијан користио сличне стилске поступке као и његов учитељ Сава.

${ }^{4}$ УП. BOJOVIĆ: 2002.
} 
рочито приликом оних молитава којима чини чуда: приликом подизања раслабљенога, на морској пучини, када моли за падање града. Доментијан за Саву каже да се толико приближио Богу постом и светим молитвама да је и мртве васкрсавао, што представља врхунац примања молитви (BOJOVIĆ 2002: 16-17).

\section{3. Похвала ${ }^{5}$}

Похвала је на граници између поетског и прозног жанра, што је чини прелазним књижевним жанром. Писана у прози, похвала је, попут поезије, лирски интонирана и химнично устројена. У структури житија она представља поджанр којим се прослављају подвизи житијног јунака, а у њој се износе разлози глорификовања одређеног свеца и она је кључно место у житију где се истиче значај његових подвига.

Похвала у Доментијановом Житију Светога Саве има веома важну улогу. Ово житије конципирано је тако да се „готово свака приповедна целина окончава похвалним местом или похвалом“ (JUHAS GEORGIEVSKA 2004: 20). Дакле, често и Доментијанова нарација одише похвалним тоном. Као да је готово кроз сваку страницу Житија Светога Саве уткана мала похвала овом великом српском светитељу.

Доментијанове похвале такође су значајно поље присуства интертекстуалних веза. У њима има поређења Саве са библијским личностима, има цитата, парафраза и алузија на библијске и на друге ауторитативне текстове.

На самом почетку Доментијановог Житија Светог Саве наилазимо на похвалу. Њу Доментијан уноси одмах након радосне вести о Савином рођењу. Стога је ова похвала антиципација будућег Савиног живота и рада на утврђивању православне вере међу Србима:

„И добро васпитан и Богом научен положи добар пример своме отачаству, и постаде велики пред Богом и испуни се Духом Светим. Јер из младости своје заволе Бога, и многи у отачаству његову заволеше Бога, подобећи се њему, и са њиме последоваше Христу од почетка и до сада се непрестано јављају изабрани Богу [...] И спреми Господу савршен народ: једне светитеље и учитеље умних стада, друге јави сваком богољубљу,

\footnotetext{
${ }^{5}$ Александра Костић Тмушић у својој књизи Поетски елементи у српској хагиографској къижевности говори о похвали у ужем и ширем смислу: „У ужем смислу, похвала представља краћи песнички став. И када се састоји из стихова, она је превасходно реторски састав“" (2017: 54). Говорећи о похвали у ширем смислу, ауторка каже да је похвала реторска проза и представља врсту слова. Стога се и веома често назива похвално слово (2017: 54).
} 
треће научи сваком правоверју. Сазда многе манастире, и породи многе зборове доброверних чрнаца Духом Светим, и научи побожности све по своме отачаству. И устроји им велик и простран пут ка Светој Гори; и у њој сазда тврде и велике градове, испуни сваким добром, и све предаде деци свога отачаства [...] И такође устроји пут у Јерусалим и у Синај и у свако место где се именује име Божје; и ваистину овај свети Илија дође к нама и ми га не познасмо по нашем жестокосрђу, а он сатвори у нама дела Божја, и отиде одакле беше дошао“ (DOMENTIJAN 1988: 65).

У овој похвали, Доментијан Саву пореди са Светим Илијом по тежини њиховог подвига, чиме прави алузију на Cmapu завет, односно на Прву и Другу Књигу Самуилову, где се говори о пророку Илији и његовом животу.

Како ће Доментијан изразити благодарност Сави и Немањи због подизања манастира Свете Богородице Хиландарске ако неће похвалом овим светитељима? Ова похвала је „састављена од 17 мањих целина, које све, осим прве, почињу бројном именицом оба, тј. Двојица““ (JUHAS GEORGIEVSKA 2004: 21). Доментијан Саву и Немању пореди са апостолима по њиховом заједничком задатку, а то је ширење православне вере: „Обојица истински апостоли, подигнути истинитим Богом на просвећење и на божаствено научење западне стране“ (1988: 94).

Овим стиховима начињена је алузија на Дела апостолска у којима је описан рад Христових апостола на ширењу хришћанске вере. Доментијан Саву и Немању у истој похвали пореди са искушаним златом „пошто се ради њихова часнога живота Христос уселио у њихове прекрасне душе, по истинитом обећању своме, будући да рече: 'Jep ћу се уселити у њих, и бићу им као Бог, и они ће ми бити народ’(II KOR. 6, 16)“ (1988: 94). Савин и Немањин живот је, дакле, испуњење божјих речи. На њима се пројавила милост Христова због многих добрих дела која су ови светитељи учинили.

Још једна библијска алузија присутна је у истој похвали. То је прича о лудим и мудрим девицама из јеванђеља: „Обојица блажене слуге, које имају будне очи у све часове, чекајући Бога свога са чистом вером“ (DOMENTIJAN 1988: 95). Сава и Немања, у Доментијановој похвали, подобни су девицама које су спремно дочекале Христов долазак, због чега су и биле награђене (МТ. 25, 1-12). Ова парабола има есхатолошки карактер, јер упућује на то да треба спремно дочекати судњи дан.

Наредна похвала у структури Доментијановог житија такође се односи на Саву и Немању. То је похвала коју Доментијан смешта у структуру житија пре описа преноса Немањиних моштију у Србију, где су Сава и Немања „небесни грађани“ (1988: 114) и још на овом пропадљивом свету „равни анђелима“ (1988: 114), једна душа, а два тела. Обојица су 
„земље доброплодне“ (1988: 115), чиме Доментијан прави паралелу са јеванђељском причом о сејачу и семену (МТ. 13, 4-23). Дакле, писац користи иста поређења као и у претходној похвали, али сада са различитим метафорама. Цела ова похвала у знаку је Доментијанове омиљене антитезе исток-запад.

Имамо у Доментијановом Житију Светога Саве и похвалу која се односи, поред Светог Саве и Светог Симеона, и на Стефана Првовенчаног. Похвала је написана након крунисања првог српског краља. У овој похвали Доментијан Немању, Стефана Првовенчаног и Саву пореди са Светом Тројицом, те „тако и имамо три светила у нашој историји“ (KOSTIĆ TMUŠIĆ 2017: 145).

Од једног ка тројици и од тројице ка једном, Доментијан се у наредној похвали враћа Сави. Он ту похвалу структурно организује као цело поглавље, Саву први пут назива „богоносцем“ (1988: 209) и пореди га са Мојсијем који је „боговидац“ (1988: 209). Цела похвала писана је кроз паралеле на релацији Сава-Мојсије, што значи да Доментијан прави паралелу са Петокюижјем Мојсијевим. Доментијан у овој похвали даје предност Сави над Мојсијем и ту његова похвална историја достиже свој врхунац.

Мојсије јесте „боговидац“ (DOMENTIJAN 1988: 209), али је Сава „богоносац“ (DOMENTIJAN 1988: 209), што је много више, јер није само Бога носио „у себи и на себи“ (DOMENTIJAN 1988: 209), већ је био ,украшен и благодаћу његовом“ (DOMENTIJAN 1988: 209). „Онај велики боговидац доби таблице закона Богом написана писмена на каменим плочама; а овај Преосвећени [...] новом апостолском благодаћу прими Светим Духом назнаменане таблице духовних поука“ (DOMENTIJAN 1988: 211).

„Онај велики боговидац, прообразујући крст победи Амалика; а овај Преосвећени је побеђивао непријатеље своје осудивши их светом молитвом и светим крсним оружјем“ (DOMENTIJAN 1988: 212). Ово место у структури житија доказ је Доментијанове употребе дела Светог Јована Дамаскина, који говори о многим примерима предизображења крста у Старом завету, као стваралачки узор и литературу: „И скоро да изоставим ширење руку Мојсијевих у виду Крста, када он поста победник над Амаликом, као што је данас Крст над ђаволом, кога предизображава Амалик“ (DAMASKIN 2002: 240). ${ }^{6}$

Овом похвалом Доментијан завршава своје похвалне говоре у Жиmију Светога Саве (KOSTIĆ TMUŠIĆ 2017: 148). Његове похвале имају

\footnotetext{
${ }^{6} \mathrm{O}$ предизображењу крста писао је Драгиша Бојовић у раду Старозаветни образ крста, где је, на бројним примерима из српске средњовековне књижевности, показано да је крст посредно деловао и у Старом завету. Уп. BOJOVIĆ 2006.
} 
„стабилизовану и униформисану структуру“ (JUHAS GEORGIEVSKA 2004: 30). Оригиналност се у њима постиже поетским средствима (симболима, песничким сликама, ефектним контрастима). Доментијан „веома брижљиво приступа конституисању похвала, поступно их припрема и реализује у оптималном моменту. Постоји добра усклађеност са ужим, али и ширим контекстом, што сведочи о пишчевом дару да изврши хармонизацију стилски разнородних структура“ (JUHAS GEORGIEVSKA 2004: 30).

\section{4. Плач}

Плач се јавља као посебан књижевни жанр у византијској књижевности (KOSTIĆ TMUŠIĆ 2017: 54). Уз плач се синонимски јављају још и називи риданије, вапај, кричаније, појмови који упућују на сам карактер плача. Термин плач издвојио се од осталих назива који се везују за ову референцу, те се овај појам најчешће користи за означавање самог књижевног жанра (TRIFUNOVIĆ 1990: 249). Он је, као и похвала, жанр прелазног карактера. Иако има одлике жанра, плач се у старој српској књижевности најчешће среће у оквиру обимније књижевне целине и тада има карактер поджанра. ${ }^{7}$ Плач је близак тужбалицама из српске народне књижевности, али и библијским изворима (Плач Јеремијин).

Александра Костић Тмушић у Житију Светога Саве утврђује два права плача и шест описа овог књижевног жанра (2017: 185). Плачевна историја у Доментијановом делу почиње онда када Ана и Немања пишу сину у Светој Гори са молбом да дође у Србију како би га видели, јер они знају да „који су са сузама сејали пожњеће са певањем“ (PS. 125, 5). Ово је, дакле, плачевна посланица Савиних родитеља (BOJOVIĆ 2011: 24).

Плач из Доментијановог Житија Светога Саве који садржи све елементе овог жанра, изговара монах Атанасије, Савин ученик, на његовом гробу. Када монаси отворе ковчег са моштима и виде Савино нетрулежно тело, Атанасије подиже Светог Саву и изговара:

„О божја, о љубазна, о слаткога и преосвећенога гласа, богогласни Саво; истинито се обећа да ћеш са нама бивати до скончања века, боголепни Саво, а ми љубима чеда твоја, имајући те као државу и богомисаону наду, сада се радујемо. Јаој, чуда, братијо, светлијег од свих чудеса, ужасног и испуњеног неисказанога дивљења. О, велика је Божја сила, и неисказана су његова чудеса јер се не распаде ни гроб онога који

${ }^{7} \mathrm{O}$ плачу у српској средњовековној књижевности није много писано, те је допринос Драгише Бојовића овој теми од изузетног значаја у науци. Он се нарочито бави питањем: Зашто је плакао Свети Сава? УП. ВОJOVIĆ 2011. 
љуби Бога и чини вољу његову, ни земља не могаде задржати но му још у животу његову и сама морска пучина послужи, а после смрти земља се не дотаче његова богоносна тела, но, штавише, као и добромирисни крин прорасте мирисима побожности онога који је из младости процветао, и, по речи пророчкој: 'ни тело његово не виде трулежа' (PS. 15, 10)“ (DOMENTIJAN 1988: 227).

Овај плач Доментијан обликује према деветој песми Канона Пасхе, када мироносице откривају да је Исус устао из гроба:

„О! божанског, о! љубљеног, о! најслађег Твога гласа!

јер си нелажно обећао да ћеш бити с нама до свршетка века, Христе.

Њега верни за утврђење наде имајући, радујемо се“

$<$ http://www.novisrbljak.narod.ru/PDF_files/Mojirad/pasha.pdf $>$

Приликом описа Савиног нетрулежног тела, Доментијан употребљава пророчке речи да „ни тело његово не виде трулежа“ (1988: 227). Овај цитат приписује се цару Давиду (PS. 15, 10), али га има и у Делима апостолским (DELA 2, 31).

Александра Костић Тмушић утврдила је и шест описа плача у Доментијановом Житију Светог Саве, од којих су два описа плача колективна (2017: 185). Њима Доментијан дочарава колико је народ у Србији туговао због Савиног останка на Светој Гори и како су Срби дочекали Симеонове мошти. Остали описи плача припадају Светом Сави. Свети Сава је плакао радосним сузама због свога пострига, сузама скрби због упокојења Стефана Првовенчаног, а истовремено и скрбним и радосним сузама након представљања Симеоновог. Радосним, јер је Симеон примио своју плату на небесима, а скрбним, јер је у овоземаљском животу изгубио саподвижника.

Последњи опис плача у структури Доментијановог Житија Светога Саве јесте приликом Савиног ходочашћа у Јерусалим. То је плач на Христовом гробу. Сава плаче од радости што га је Господ удостојио да ходи путевима Сина божјег (KOSTIĆ TMUŠIĆ 2017: 187-190).

\section{5. Посланица}

Посланица припада епистоларној књижевности, а њено порекло датира још од античких реторских правила фиксираних у формуларном облику писмовних образаца (BOGDANOVIĆ 1980: 74). У српску средњовековну књижевност посланице су дошле преко византијске књижевности, где су представљале веома прихваћен и често коришћени жанр. Ђорђе Трифуновић посланице дели на личне (приватне), које су део свакодневне 
преписке владара, црквених достојника, обичних људи, и на књижевне, какве су посланице светих апостола у Новом завету (1990: 264-271). Српски средњовековни животописци често их инкорпорирају у житија и тада посланице представљају поджанр у оквиру обимније прозне целине.

Поглавље III из Доментијановог житија: O писағу преподобнога Саве ка родитељима и о звању оца свога у Свету Гору, скоро да је цело написано у виду посланице. Ово место веома је важно у структури Житија Светога Саве, јер је оно мотивациони агенс за Немањин одлазак на Свету Гору. Сава га, у овој посланици која одише љубављу и поштовањем према родитељу, топло позива да му се придружи у његовом овоземаљском подвигу. О томе сведоче Савине речи: „Господине мој и оче чедољупче, источна звездо Данице“ (DOMENTIJAN 1988: 72). И да нема у житију других примера Савине љубави према оцу, овај један био би довољан да посведочи о томе. Сава овде говори оцу да је и он „ревнујући поревновао“ (I CAR. 19, 10; 19, 14) по Господу који га је „узео“ (PS. 27, 10) себи, уздајући се у божје речи да „онога који греде ка њему неће изагнати ван“ (JN. 6, 37). Сава саветује Немањи да је њему ,добро приањати Богу“ (PS. 73, 28), те моли свога оца да и он, последујући њему, дође на Свету Гору (DOMENTIJAN 1988: 72). У овој посланици садржана је Савина вера у Господа, увереност да иде уским, али правим путем, жеља да спасе пропадања свога родитеља позивајући га на саподвижништво у монашком животу, похвала и љубав Савина према Господу. Она представља и компилацију најразличитијих библијских цитата, парафраза и алузија, које се, попут мозаика, уткивају у текст посланице.

Следеће две посланице које су важне у Доментијановом житију јесу она у којој Стефан Првовенчани моли Саву да пренесе Немањине мошти у Србију и Савин одговор Стефану у коме му јавља да ће његова жеља бити услишена. И оне су сведочанство о великој братској љубави о којој је говорио Јован Богослов у својим Посланицама (I, II и III JN). Савину посланицу до речи „господин“ (1988: 113), Доментијан преузима из Житија Светог Симеона Стефана Првовенчаног парафразирајући је. Поменуто место из житија доказ је да су средњовековни писци користили као изворе и друга средњовековна дела и ауторе.

\section{6. Беседа}

Реторска природа средњовековне прозе нарочито се огледа у беседи. ${ }^{8}$ Она се у српској књижевности врло рано јавља као жанр (TRIFUNOVIĆ

${ }^{8}$ Синоним за беседу је слово, а оно се дефинише као „говор или проповед на одређену тему из Библије или црквеног календара, но исто тако и на посебну моралистичку тему“ (BOGDANOVIĆ 1980: 74). 
1990: 28), а када се нађе у структури обимнијег прозног текста, беседа постаје поджанр.

Српским средњовековним писцима најближи узор су Христове беседе из Новог завета. Оне представљају скуп етичких учења и изрека, а Беседа на гори сматра се програмским делом у коме је изложено читаво Христово учење.

У Доментијановом делу, беседе представљају важно место испољавања Савине животне мисије. Сава у својим беседама говори о правој вери и прославља Бога. Прва Савина беседа у житију јесте она коју светитељ изговара након преноса Симеонових моштију у Србију. Доментијан је назива Поученијем Светога Саве ка свему сабору његова отачаства о преподобном Симеону. Дакле, ово је поученије којим светилник отачаства свога треба да просвети свој народ, говорећи му, на Симеоновом примеру, о сладости православне вере. Ова беседа је важна зато што се преплиће са похвалним жанром, јер Доментијан у беседу о правој вери и божјој награди уткива похвалу Светом Симеону:

„Да, ваистину, овај преподобни отац наш тако заволи Бога и усрдно му последова, да ниједној од светих заповести његових не даде да падне на земљу“ (1988: 119), већ последова речима божјим: „ко претрпи до краја биће спасен’ (МТ. 10, 22) и „за толико љубазно му течење, удостоји га Владика цар небесни, да је и сретник био његових светих [...] још нам и чудеса показа кроз њега, да болнима даје здравље и бесове изгони и после смрти““ (1988: 119).

Поука преосвећенога кир Саве на светоме сабору Лавре свете Богородице важна је за структуру житија, али је значајна и за Савину духовну и световну делатност. Он, последујући речима Светог апостола Павла: „Пазите умно стадо ваше у које вас постави Дух Свети као пастире и учитеље“ (DELA 20, 28), каже окупљенима: „Да, и мени уздигнутом на овај степен, од сада није ми лепо ћутати, нити да гледајући ми своје ствари будем најамник, а не истинити пастир“ (DOMENTIJAN 1988: 144).

Савин живот је испуњење божјих заповести. Он зна да му, уздигнутом на архиепископски чин, није лепо ћутати. Сава је свој задатак добро разумео и тежи да га, последујући божанским речима, богоугодно изврши. Уплашивши се новозаветног најамника, он тежи да буде истинити nастир. Зато одлучује да беседи о правој вери увек када има прилику за то. И заиста, након ове поуке, Савине беседе у житију ће се умножити.

Прву заповест коју Сава даје својим ученицима јесте да се „прво држимо праве вере“ (DOMENTIJAN 1988: 148), а другу да имамо љубав међу собом, јер: „вера спасава љубављу делајући“ (GAL. 5, 6). Сава проповеда о Светој Тројици као јединосушној, а трипостасној, па у наставку ове беседе, због чега је она и значајна, разлаже и парафразира Симбол вере: 
„И верујемо у једнога од Тројице, ни Оца ни Светога Духа, но Сина и Бога који се од Бога Оца родио [...] који је увек с њим, који је добротом све привео из небића у биће [...] од Бога Оца јединосушно му Бог Слово, који је због множине човекољубља вољом Оца и Духа изволео спасти своје саздање“" (DOMENTIJAN 1988: 149). Сава говори о Христовој жртви који је „распет безгрешан“ (DOMENTIJAN 1988: 149) и који „окуси и смрт, и трећи дан ускрсе телом, не видевши трулежи [...] и на небеса узневши се, седе с десне стране Оца““ (DOMENTIJAN 1988: 149-150).

Дакле, Доментијан из Симбола вере преузима дословне стихове. Одмах затим следи парафраза Јованових речи, које се надовезују на цитате из Симбола вере: „Јер васкрснуће, рече, мртви и устаће они који су у гробовима, и они који су сатворили добро са правом вером поћи ће у васкрсење живота, а они који су сатворили зло, у васкрсење суда“ (JN. 5, 28-29) (DOMENTIJAN 1988: 149-150).

Доментијанов љубљени учитељь и на двору угарског краља изговара беседу о Богу која прераста у беседу о љубави. Ово Доментијаново слово прво је слово о љубави у нашој средњовековној књижевности. Доментијан овде наводи један неидентификован цитат, који приписује светопевиу: „Ка матери својој какову имате љубав, ка Богу дужни смо имати још већу и топлију љубав“" (DOMENTIJAN 1988: 163). Мисао блиску овој налазимо код Светог Јована Лествичника: „Мати није тако привржена свом одојчету како је син љубави свагда привржен Господу“ (BOJOVIĆ 2009b: 87). Поменути навод показатељ је присуства патристичких извора у Савином слову о љубави, али и светоотачке литературе коју је Доментијан радо читао.

Сава ће на двору угарског краља говорити и о вазљубљенима. Он богољупце назива вазљубљенима по угледу на Јована Богослова и у својој беседи дефинише овај појам: „Јер Богом бише синови човечји названи љубазним именом вазљубљени. Зато рече Јован апостол: 'Вазљубљени, љубимо један другога, као што је Бог љубав’ (I JN. 4, 9)“ (DOMENTIJAN 1988: 164).

У наставку слова, Сава подсећа на Христово учење које је извор сладости хришћанског живота и говори о нужности поимања Христове науке кроз љубав:

„А сада одбацивши сваку горчину и сувишак злобе, у кротости примите истиниту реч (JAKOVLJ. 1, 21) и самисаоно млеко, да у њему узрастете у његово спасење (I PETR. 2, 2). А сву сладост учења Господњег и светих његових апостола треба примити с љубављу и са трпљењем, чувајући до краја савршено дело. Јер ко хоће да сатвори што добро у Богу, сам Бог љуби га и помаже му, јер све је љубављу предао примити у овом и будућем веку“ (DOMENTIJAN 1988: 164). 
Последњи стихови ове беседе представљају спој цитата из посланица апостола Петра и апостола Јакова. ${ }^{9}$

Савино слово о љубави завршава се похвалом љубави која је Христос, ,,jер Бог је љубав“ (I JN. 4, 8), као што рече Јован Богослов.

Дакле, Доментијан се, пишући ову беседу, пре свега ослања на новозаветно поимање љубави, те као изворе за аутентичност свога слова о зубави, користи наводе Светих апостола Петра и Павла, апостола Јакова, као и јеванђелиста Матеја и Јована. Једно место овога слова о љубави садржи комбинацију стихова Светог апостола Петра и апостола Јакова, а Доментијан користи и патристичко поимање љубави, позивајући се на Светог Јована Лествичника и Светог Јефрема Сирина.

Драгиша Бојовић у тексту Доментијан и софиологија Светог апостола Павла ${ }^{10}$ говори о софиолошком утицају божанственог апостола који се базира на Павловим речима да је Христос „божја сила и божја премудрост“ (I KOR. 1, 24). Први који је идентификовао једну мисао из софиологије Светог апостола Павла у Савиној Беседи о правој вери био је епископ Атанасије Јевтић (JEVTIĆ 2004: 88). Доментијан је интерполира у житије када на Савина уста говори о Христу као премудрости и сили очевој:

„Јер учење духовно није игра нити безумље мисли човечјих, но света вера проповедана, на којој бише основани сви свети чинови о Христу Исусу Господу нашем, о коме пророци Светим Духом Божјим прорекоше, и апостоли научише, и мученици исповедаше, и сви свети сахранише, и преподобни оци без порока сачуваше, као на непресеченом крајеугаоном камену црквеном, Христу, који је премудрост очева и сила (I KOR. 1, 24)“ (1988: 152).

Друго место у Доментијановом житију где се очитује Павлов софиолошки утицај јесте Друга жичка беседа. Наведена софиолошка идеја изречена је сада у контексту поуке о следовању, где Сава позива своје ученике да следе његов пут (BOJOVIĆ 2014: 573) речима:

„Да, пожурите се, чеда моја и другови, да својим добрим делима сатворите угодно пред Господом Богом вашим, и као што видите мене, последујте ми, и идите за мном, и нас све неће обличити крмитељ вечних добара у бесконачне векове, Господ наш Исус Христос Син Божји, премудрост Оца и сила, сам све добро свршавајући својом силом, и без њега нико не може сатворити никаква добра““ (DOMENTIJAN 1988: 186).

\footnotetext{
${ }_{9}^{9}$ Ово место није било утврђено до појаве Трпезе премудрости Драгише Бојовића. Уп. BOJOVIĆ 2009b.

${ }^{10}$ УП. BOJOVIĆ 2014.
} 
Ако за Доментијаново Житије Светога Саве кажемо да представља прозни мозаик српске средњовековне књижевности, биће јасно да је оно богато бројним поджанровима који се, попут минијатурних мозаичних делова, уклапају у јединствену и складну целину. Поджанровски систем овог дела чине: молитва, похвала, плач, посланица и беседа, које својим комбинацијама и варијацијама могу творити и хибридне поджанрове као што су похвално слово, похвална посланица, плачевна посланица и сл. Доментијан не само да преузима моделе ових жанрова из византијске књижевности, већ их и самостално саставља по узору на ауторитете и њихов садржај богати изворима српске црквене и књижевне традиције која му је била на располагању.

Доментијан у своје дело радо уноси библијске, светоотачке и богослужбене текстове, који су показатељи извора пишчеве учености. Код овог средњовековног писца, интертекстуалност је заступљена у виду дословних цитата, парафраза, алузија, али и у виду паралела са ауторитативним текстовима. Када је реч о Светом писму, овај средњовековни писац најчешће из Новог завета преузима јеванђељске наводе, али користи и цитате из Дела апостолских. Из Старог завета, Доментијан највише цитира Псалме Давидове, али и Петокњижје Мојсијево, те Кюиге Самуилове.

Комбинација Давидових Псалама у Доментијановом делу најчешћа је у структури молитве. Када је реч о конституисању плача, Доментијан, као и остали средњовековни писци, то чини по узору на Плач Јеремијин, али у своје плачеве уноси и литургијске интертекстове попут стихова из Канона Пасхе Светог Јована Дамаскина. Своје посланице Доментијан обликује по узору на посланице светих апостола, а беседе по узору на Христове беседе. Од патристичких извора у Доментијановим поджанровима, утврђен је утицај Светог Јована Лествичника, Светог Јефрема Сирина и Светог Јована Дамаскина.

Ваља напоменути да се овим радом не исцрпљује присуство поджанрова и интертекстуалних веза у Доментијановом Житију Светога Саве, међутим, њихов целокупан попис и детаљнија анализа превазишли би оквире овог рада, због чега смо се задржали само на најрепрезентативнијим примерима из дела.

\section{Цитирана литература}

ANĐELKOVIĆ 2019: ANĐELKOVIĆ, Maja. Žitije Svetog Simeona $i$ intertekstualnost. Godišnjak centra za crkvene studije, br. 16/1. Niš: Centar za crkvene studije, 2019. [orig.] АНЂЕЛКОВИЋ, Маја. Житије Светог Симеона и интертекстуалност. Годишњак Центра за црквене студије бр. 16/1. Ниш: Центар за црквене студије, 2019. 
BOGDANOVIĆ 1980: BOGDANOVIĆ, Dimitrije. Istorija stare srpske književnosti. Beograd: SKZ, 1980. [orig.] БОГДАНОВИЋ, Димитрије. Историја старе српске књижевности. Београд: СКЗ, 1980.

BOJOVIĆ 2014: BOJOVIĆ, Dragiša. Domentijan i sofiologija Svetog apostola Pavla. Glasnik SPC, br. 10, 2014. [orig.] БОЈОВИЋ, Драгиша. Доментијан и софиологија Светог апостола Павла. Гласник СПЦ, бр. 10, 2014.

BOJOVIĆ 2011: BOJOVIĆ, Dragiša. Antologija plača. Izbor, predgovor i propratni tekstovi Dragiša Bojović. Niš: Prosveta, Kragujevac: Grafostil, 2011. [orig.] БОЈОВИЋ, Драгиша. Антологија плача. Избор, предговор и пропратни текстови Драгиша Бојовић. Ниш: Просвета, Крагујевац: Графостил, 2011.

BOJOVIĆ 2009a: BOJOVIĆ, Dragiša. Ponavljanje patrističkih citata u srpskoj crkvenoj književnosti, Philologia Mediana, god. 1, br. 1, Niš, 2009a [orig.] БОЈОВИЋ, Драгиша. Понављање патристичких ичтата у српској црквеној књижевности, Philologia Mediana, год. 1, бр. 1, Ниш, 2009а.

BOJOVIĆ 2009b: BOJOVIĆ, Dragiša. Trpeza premudrosti. Beograd: Raška škola, Niš: Centar za crkvene studije, 2009b [orig.] БОЈОВИЋ, Драгиша. Трпеза премудрости. Београд: Рашка школа, Ниш: Центар за црквене студије, 20096.

BOJOVIĆ 2006: BOJOVIĆ, Dragiša. Starozavetni obraz krsta. Godišnjak centra za crkvene studije, 3, Niš, 2006. [orig.] БОЈОВИЋ, Драгиша. Старозаветни образ крста. Годишњак Центра за црквене студије, 3, Ниш, 2006.

BOJOVIĆ 2002: BOJOVIĆ, Dragiša. Molitve Svetoga Save. Prir. Dragiša Bojović. Niš: Centar za crkvene studije, Punta, Kosovska Mitrovica: Filozofski fakultet, 2002. [orig.] БОЈОВИЋ, Драгиша. Молитве Светога Саве. Прир. Драгиша Бојовић. Ниш: Центар за црквене студије, Пунта, Косовска Митровица: Филозофски факултет, 2002.

BUŽINJSKA, MARKOVSKI 2009: BUŽINJSKA, Ana. Mihail Pavel Markovski. Književne teorije XX veka. Beograd: Službeni glasnik, 2009.

DAMASKIN 2002: DAMASKIN, Jovan, Sveti. Besede. Prev. Episkop Atanasije. Trebinje, Vrnjci, 2002. [orig.] ДАМАСКИН, Јован, Свети. Беседе. Прев. Епископ Атанасије. Требиње, Врњци, 2002.

DAMASKIN, Jovan, Sveti. Kanon Pashe. $<$ http://www.novisrbljak.narod.ru/ PDF_files/Mojirad/pasha.pdf>. 11. 10. 2019. [orig.] Дамаскин, Јован, Свети. Канон Пасхе. <http://www.novisrbljak.narod.ru/PDF_files/Mojirad/ pasha.pdf $>$. 11. 10. 2019.

JEVTIĆ 2004: JEVTIĆ, Atanasije. Bogoslovlje Svetog Save. Vrnjci, Trebinje, 2004. [orig.] JЕВТИһ, Атанасије. Богословље Светог Саве. Врњци, Требиње, 2004.

JUHAS GEORGIEVSKA 2001: JUHAS GEORGIEVSKA, Ljiljana. Književno delo jeromonaha Domentijana. Predg. Žitiju Svetoga Save, Domentijan. Beograd: SKZ, 2001. [orig.] JУХАС ГЕОРГИЕВСКА, Љиљана. Књижев- 
но дело јеромонаха Доментијана. Предг. Житију Светога Саве, Доментијан. Београд: СКЗ, 2001.

JUHAS GEORGIEVSKA 2004: JUHAS GEORGIEVSKA, Ljiljana. Principi konstituisanja i uloga mikro-žanrova u Domentijanovom Životu Svetog Save. Naučni sastanak slavista u Vukove dane. Beograd: Međunarodni slavistički centar na Filološkom fakultetu, 2004. [orig.] JУХАС ГЕОРГИЕВСКА, Љиљана. Принџипи конституисања и улога микро-жанрова у Доментијановом Животу Светог Саве. Научни састанак слависта у Вукове дане. Београд: Међународни славистички центар на Филолошком факултету, 2004.

KOSTIĆ TMUŠIĆ 2017: KOSTIĆ TMUŠIĆ, Aleksandra. Poetski elementi u srpskoj hagiografskoj književnosti. Priština, K. Mitrovica: Filozofski fakultet, Niš: Međunarodni centar za pravoslavne studije, Valjevo: Valjevo print, 2017. [orig.] КОСТИЋ ТМУШИЋ, Александра. Поетски елементи у српској хагиографској књижевности. Приштина, К. Митровица: Филозофски факултет, Ниш: Међународни центар за православне студије, Ваљево: Ваљево принт, 2017.

NAUMOV 2009: NAUMOV, Aleksandar. Staro i novo. Niš: Centar za crkvene studije, 2009. [orig.] НАУМОВ, Александар. Старо и ново. Ниш: Центар за црквене студије, 2009.

TRIFUNOVIĆ 1990: TRIFUNOVIĆ, Đorđe. Azbučnik srpskih srednjovekovnih književnih pojmova. Beograd: Nolit, 1990. [orig.] ТРИФУНОВИЋ, Ђорђе. Азбучник српских средњовековних књижевних појмова. Београд: Нолит, 1990.

\section{Извори:}

BIBLIJA: Sveto pismo Staroga i Novoga zavjeta. Prev. Đuro Daničić i Vuk Stefanović Karadžić. Beograd: Glas mira, Preporod, 2009. [orig.] Библија: Свето писмо Старога и Новога завјета. Прев. Ђуро Даничић и Вук Стефановић Караџић. Београд: Глас мира, Препород, 2008.

DOMENTIJAN 1988: Domentijan. Život Svetoga Save i Život Svetoga Simeona. Prir. R. Marinković, prev. Lazar Mirković. Beograd: Prosveta, Srpska književna zadruga, 1988. [orig.] Доментијан. Живот Светога Саве и Живот Светога Симеона. Прир. Р. Маринковић, прев. Лазар Мирковић. Београд: Просвета, Српска књижевна задруга, 1988. 
Sara N. Nemat

\section{INTERTEXTUAL LINKS IN THE SUBGENRES OF DOMENTIAN'S LIFE OF SAINT SAVA}

The paper defines (sub)genre traits in Domentian's Life of Saint Sava and establishes intertextual links in them. Has been noticed that every subgenre invokes authoritative (Byzantine) genres and that it was constituted after their model. At the same time, the genres in the old Serbian literature do not exist separately but are in a relationship of permeation. The aim of this paper is to determinate sources of the citations in subgenres as well as pointing out the degree of presence of intertextuality in Domentian's Life of Saint Sava.

Key words: biography, (sub)genre, prayer, praise, cry, epistle, sermon, intertextuality, intertextual links, Domentian 